\title{
PENGARUH PENERAPAN BUDAYA DEMOKRASI DI LINGKUNGAN SEKOLAH TERHADAP PEMBENTUKAN CIVIC SKILLS
}

\author{
DEVRITA AYU PUTRI DESTIAWAN \\ IIK STRADA INDONESIA ( S1 FARMASI ) \\ devritaayu1@gmail.com
}

\begin{abstract}
ABSTRAK
Metode dalam penelitian ini menggunakan deskriptif kuantitatif. Subjek penelitian seluruh siswa dengan sampel 48 siswa. Teknik pokok menggunakan angket, sedangkan wawancara dan dokumentasi sebagai teknik penunjang. Teknik analisis data menggunakan chi kuadrat. Berdasarkan hasil penelitian yang telah dilakukan dapat diketahui bahwa terdapat derajat keeratan, yaitu dengan koefisien kontingensi $\mathrm{C}=0,63$ dan koefisien kontingensi $\mathrm{Cmaks=0,81}$.
\end{abstract}

Kata kunci: Budaya demokrasi, civic skills, penerapan budaya

\section{Latar Belakang}

Indonesia menganut sistem pemerintahan demokrasi, ini telah tercantum dalam Undang-Undang Dasar 1945 (setelah amandemen) pasal 1 ayat 1 berbunyi berada di tangan rakyat dan dilaksanakan menurut Undang dalam Undang-Undang Dasar sementara 1950 pada pasal 1 ayat (1). Sebagai negara yang beragam etnik, bahasa, agama, budaya, serta kelompok sosial Indonesia memiliki tantangan tersendiri. Tantangan utama bangsa Indonesia yaitu bagaimana menyatukan perbedaan dalam suata tatanan masyarakat yang demokratis. Masyarakat yang demokratis dapat tercipta apabila semua masyarakat dapat mengenal, percaya dan memiliki komitmen satu sama lain. Indonesia salah satu negara yang menganut sistem demokrasi, semua elemen bangsa perlu menerapkan nilai nilai demokrasi. Nilai-nilai demokrasi hendaknya dapat diterapkan dalam kehidupan nyata salah satunya melalui pendidikan, khususnya Pendidikan Kewarganegaraan yang merupakan mata pelajaran yang memfokuskan pada pembentukan warga negara yang demokratis, memahami dan mampu melaksanakan hak-hak dan kewajibannya untuk menjadi warga negara Indonesia yang cerdas, terampil dan berkarakter yang diamanatkan oleh Pancasila dan Undang-Undang Dasar 1945. Membentuk warga negara yang demokratis tidak terlepas dari peran guru di sekolah yang mengajarkan siswa-siswinya untuk bersikap demokratis. Seorang guru tidak hanya menyampaikan materi-materi mata pelajaran di kelas tetapi harus dapat memberi contoh penerapan nilai-nilai demokrasi di lingkungan sekolah karna keterlibatan siswa dalam menerapkan nilai-nilai demokrasi di lingkungan sekolah sangat besar pengaruhnya. Sekolah sebagai Lembaga Pendidikan ke dua setelah pendidikan keluarga menjadi tempat dalam proses penanaman budaya demokrasi bagi penerus bangsa. Sekolah memiliki peran penting dalam menumbuhkan budaya demokrasi di kalangan pelajar. Oleh karena itu, sekolah harus menampilkan budaya demokrasi 
dalam pengelolaan pendidikannya. Disini siswa akan belajar bagaimana budaya demokrasi itu dapat terwujud dan dapat dilaksanakan dengan baik. Di sekolah siswa akan di belajarkan bahwa demokrasi sudah menjadi budaya, berarti nilai-nilai demokrasi sudah menjadi kebiasaan bagi warga negara untuk dilaksanakan. Akan tetapi yang sering terlihat di media masa bahwa warga negara bahkan pemerintah itu sendiri telah melanggar nilai-nilai demokrasi, banyak orang yang kurang menghargai kebebasan orang lain, kurang menghargai perbedaan, dan supremasi hukum kurang ditegakkan. Bahkan dalam keluarga dan masyarakat kita sendiri, nilai-nilai demokrasi kurang dipraktekan. Maka dari kasus yang terjadi ini sekolah dapat mengajarkan siswa-siswi agar bisa menjalani nilai-nilai demokrasi dengan baik dan benar agar bisa menjadi penerus bangsa yang baik, adil, dan jujur. Faktanya saat ini sekolah juga dapat menciptakan pendidikan demokrasi yang dapat menjadi salah satu upaya strategis pendemokrasian bangsa Indonesia, khususnya dikalangan generasi muda. Pendidikan yang dimaksud adalah model Pendidikan yang berorientasi pada pembangunan karakter bangsa melalui pembelajaran yang menjadikan peserta didik sebagai subjek pembelajaran melalui pembelajaran yang demokratis, partisipatif, kritis, kreatif dan membentuk aktualisasi diri mereka. Pendidikan model ini sangat releven bagi pengembangan pendidikan demokrasi. Sebagai komponen warga negara, pengalaman siswa dalam praktik berdemokrasi dikelas akan sangat berharga bagi proses transformasi nilainilai demokrasi dalam kehidupan sosial. Untuk mewujudkan tujuan tersebut sekolah harus menciptakan budaya demokrasi yang terlibat dalam pendidikan atau dalam lingkungan sekolah.

Menciptakan budaya demokrasi yang baik di lingkungan sekolah tidaklah mudah harus di dukung oleh semua warga sekolah, dengan terlaksananya sistem musyawarah di dalam pengambilan keputusan, terbentuknya organisasiorganisasi sekolah, adanya saling menghargai dan menghormati keberadaan individu maupun kelompok di sekolah, dan dukungan sekolah dalam memfasilitasi kegiatan kesiswaan baik dalam kurikuler maupun ekstrakurikuler itu merupakan contoh sikap budaya demokrasi yang baik di lingkungan sekolah.

\section{Kasus/Masalah}

Siswa harus mempunyai pola piker bahwa budaya demokrasi itu penting, agar jiwa demokrasinya sejak awal terbentuk, oleh karna itu sekolah harus mengkondisikan suasana sekolah yang demokratis serta menyediakan sarana dan prasarana yang membangun kebiasaan kebiasaan demokratis di lingkungan siswa. Hal inilah yang akan memotivasi siswa untuk melaksanakan kegiatan kegiatan yang ada di sekolah, karena kegiatan di sekolah merupakan pengalaman berharga untuk masa depan dalam menjalankan budaya demokrasi di masyarakat.

\section{Tinjauan Pustaka}

Salah satu keunikan dan keunggulan sebuah sekolah adalah memiliki budaya sekolah yang kokoh dan tetap eksis. Perpaduan semua unsur baik siswa, guru dan orang tua yang berkerjasama dalam menciptakan komunitas yang lebih baik melalui Pendidikan yang berkualitas, serta bertanggung jawab dalam meningkatkan mutu pembelajaran di sekolah, menjadikan sebuah sekolah unggul dan favorit di masyarakat. Menurut Handoko (2007:16) implikasi yang mendasar dari budaya demokrasi, bahwa kehadiran dan keberadaan siswa sebagai salah satu komponen sekolah hanya akan diterima, 
apabila yang bersangkutan mau, mampu, dan bersedia melakukan berbagai jenis penyesuaian dalam tindakan dan perilakunya mencerminkan penerimaan terhadap budaya demokrasi sesuai dengan tujuan program-program sekolah. Sebuah sekolah harus mempunyai misi menciptakan budaya sekolah yang menantang dan menyenangkan, adil, kreatif, terintegratif, dan dedikatif terdahap pencapaian visi, menghasilkan lulusan yang berkualitas tinggi dalam perkembangan intelektualnya dan mempunyai karakter takwa, jujur, kreatif, mampu menjadi teladan, bekerja keras, toleran dan cakap dalam memimpin, serta menjawab tantangan akan kebutuhan pengembangan sumber daya manusia yang dapat berperan dalam perkembangan iptek dan berlandasan imtak. Budaya demokrasi bersifat intangible (tidak dapat diraba) karena tidak dapat dilihat atau disentuhnya, tetapi ada dan dapat dirasakan manfaatnya seperti udara dalam ruangan. Budaya melingkungi dan memperngaruhi apa saja yang terjadi dalam lingkungan. Budaya merupakan sebuah konsep sistem yang dinamis, sehingga dapat dipengaruhi oleh apa saja yang terjadi dalam sebuah organisasi. Selain budaya di sekolah ada kata lain untuk mengembangkan diri siswa yaitu dalam kegiatan berdemokrasi di sekolah. Siswa dapat belajar hidup berdemokrasi di dalam lingkungan sekolah, karna pengembangan ini sangat penting di dapat oleh siswa karena budaya demokrasi adalah kebiasaankebiasaan yang dilakukan oleh masyarakat Indonesia dalam kegiatan berpolitik. Di dalam kegiatan ini siswa harus ikut berpartisipasi dalam kegiatan berpolitik yang ada di sekolah. Contohnya seperti dalam pemilihan ketua kelas, pemilihan ketua OSIS dan siswa dapat berpartisipasi dalam kegiatan-kegiatan yang ada di sekolah. 1. Civic Skills (Kecakapan Kewarganegaraan)
Kecakapan kewarganegaraan merupakan suatu kemampuan untuk menerapkan pengetahuan kewarganegaraan yang telah dikuasai warga negara. Dalam masyarakat demokratis warga negara hendakya mampu melaksanakan kewajiban-kewajiban, serta bertanggung jawab atas segala tindakantindakannya, disamping hak-hak yang diperolehnya. Dengan demikian terdapat adanya keseimbangan antara hak dan kewajiban lebih diutamakan daripada hak. Kecakapan kewarganegaraan dalam hal ini meliputi kecakapan intelektual serta kemampuan berpartisipasi secara aktif dalam berbagai masalah warga negara. Life skills atau keterampilan hidup dalam pengertian ini mengacu pada berbagai ragam kemapuan yang diperlukan seseorang untuk menempuh kehidupan dengan sukses, bahagia dan secara bermartabat di masyarakat. Life skills merupakan kemampuan yang diperlukan sepanjang hayat, kepemilikan kemampuan berpikir yang kompleks, kemampuan komunikasi secara efektif, kemampuan membangun kerjasama, melaksanakan peranan sebagai warga negara yang bertanggung jawab, memiliki kesiapan serta kecakapan untuk bekerja, dan memiliki karakter dan etika untuk terjun ke dunia kerja. 2. Intelektual Skills (Kecakapan Intelektual) Kecakapan intelektual atau kemampuan berpikir ilmiah, pada dasarnya merupakan pengembangan dari kecakapan berpikir secara umum, namun mengarah kepada kegiatan yang bersifat keilmuan dan lebih diarahkan kepada kecakapan berpikir kritis, kreatif tentang berbagai masalah kewarganegaraan. Branson (1999: 15-16) mengemukakan berikut ini adalah kata-kata yang biasa digunakan untuk mengidentifikasikan kecakapan intelektual: Kemampuan intelektual: kata-kata berikut ini sering digunakan untuk mengidentifikasi kemampuan intelektual: a. Mengidentifikasi: untuk mengenali dengan jelas sesuatu yang masih samar yaitu seseorang harus mampu (1) membedakannya dengan yang lain,(2)mengklasifikasikannya dengan sesuatu yang lain yang memiliki 
kesamaan,(3) menentukan asal-usulnya.

b. Mendeskripsikan: untuk mendeskripsikan objek, proses, institusi, fungsi, tujuan, alat dan kualitas yang jelas maupun yang samar. Agar dapat mendeskripsikan, seseorang memerlukan laporan tertulis atau verbal tentang karakteristiknya.

c. Menjelaskan: untuk mengidentifikasikan, mendeskripsikan, mengklarifikasi, atau menerjemahkan sesuatu, seseorang dapat menjelaskan (1) sebab-sebab suatu peristiwa (2) makna dan pentingnya suatu peristiwa atau ide.

d. Mengevaluasi posisi: untuk menggunakan kriteria atau standar guna membuat keputusan mengenai (1) kekuatan dan kelemahan posisi suatu isu tertentu, (2) tujuan yang dikedepankan posisi itu, atau (3) alat yang dipakai untuk mencapai tujuan itu. e. Mengambil sikap/posisi: untuk menggunakan kriteria atau standar guna mencapai suatu posisi seseorang dapat mendorong (1) memilih dari berbagai alternatif pilihan, atau (2) membuat pilihan baru.

f. Membela posisi: untuk (1) mengemukakan argmen atas sikap yang diambil dan (2) merespon argumentasi yang tidak disepakati 3. Partisipatoris Skills (Kecakapan Partisipasi) Di samping mensaratkan pengetahuan dan kemampuan intelektual, pendidikan untuk warga negara dalam masyarakat demokratis harus difokuskan pada kecakapankecakapan yang dibutuhkan untuk berpartisipasi yang bertanggung jawab, efektif, dan ilmiah, dalam proses politik dan dalam civil society. Kecakapan-kecakapan tadi itu, dapat dikategorikan sebagai interaksi (interacting), memonitoring (monitoring), dan mempengaruhi (influencing). Interaksi berkaitan dengan kecakapan-kecakapan warga negara dalam berkomunikasi dan bekerjasama dengan orang lain. Branson (1998: 15-16) mengemukakan mengenai kata-kata untuk lebih memahami mengenai kecakapan intelektual. Berikut ini adalah kata-kata yang biasa digunakan untuk mengidentifikasi kecakapan partisipatoris:
Kemampuan partisipatoris:

a. Kemampuan untuk mempengaruhi kebijakan dan keputusan dengan bekerjasama dengan yang lain.

b. Memaparkan dengan gamblang suatu masalah yang penting sehingga membuatnya diketahui oleh para pembuat kebijakan dan keputusan.

c. Membangun koalisi, negosiasi, kompromi, dan mencari konsensus.

d. Mengelola konflik.

\section{Pembahasan}

Berdasarkan hasil pengolahan data dan pengujian hipotesis di atas dapat diketahuibahwa terdapat derajat keeratan, yaitu dengan koefisien kontigensi $\mathrm{C}=0,63$ dan koefisien

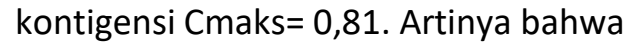
terdapat pengaruh yang sangat kuat bahwa terdapat pengaruh yang sangat kuat pada penerapan budaya demokrasi di lingkungan sekolah terhadap pembentukan civic skills. Bahwa pelaksanaan program, target kelompok, dan responsibility saling bersinergi/berpengaruh satu sama lain membentuk budaya demokrasi di lingkungan sekolah dengan kata lain pelaksanaan program menjadi pedoman pencapaian target kelompok yang dalam pelaksanaannya akan dipertanggungjawabkan oleh seluruh komponen sekolah meliputi guru dan siswa untuk mewujudkan pembentukan civic skills.

\section{Kesimpulan}

Berdasarkan hasil pengolahan data dan pengujian hipotesis yang telah dilakukan, maka dapat disimpulkan bahwa terdapat pengaruh yang signifikan antara penerapan budaya demokrasi di lingkungan sekolah terhadap pembentukan civic skill. Hal ini dapat di 
lihat berdasarkan pada beberapa

indikator mengenai penerapan budaya

demokrasi di lingkungan sekolah yang

meliputi pelaksanaan program, target

kelompok dan responsibility. Kemudian

pada indikator pembentukan civic skills

yang meliputi indikator intelektual skills

dan partisipatoris skills.

\section{Daftar Pustaka}

Branson, S Margareth, et.al. 1999. Belajar Civic Education dari Amerika.

Yogyakarta: LkiS.

Handoko. 2007. Manajemen Personalia \& Sumber Daya Manusia. Jakarta: Rineka Cipta.

Winataputra, U.S. dan Dasim

Budimansyah, 2007. Civic Education , Koteks,

Landasan, Bahan Ajar dan Kultur Kelas.

Bandung: UPI

Siyoto, S., \& Sodik, M. A. (2015). Dasar metodologi penelitian. Literasi Media Publishing.

DESTIAWAN, D. A. P. (2021). Hak dan Kewajiban Pola Hidup Sehat Melalui Food Combining Di Ranah Komunikasi

Kesehatan. 